IJBPAS, October, Special Issue, 2021, 10(10): 129-138

ISSN: 2277-4998

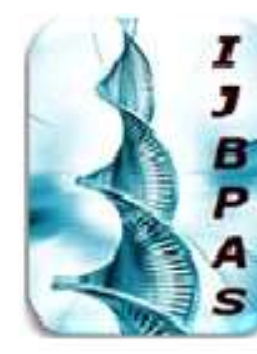

International Journal of Biology, Pharmacy and Allied Seiences (IJBPAS) 'A Bridge Betueen Caboratory and Q ando'

WwW.ijbpas.com

\title{
PREVALENCE STUDY OF TEST ANXIETY IN AYURVEDA \\ UNDERGRADUATES OF KARNATAKA THROUGH SEMI STRUCTURED ONLINE SURVEY
}

\section{NIVEDITHA CN ${ }^{1}$, KALE AK ${ }^{2}$ AND SHETTY SK ${ }^{3}$}

1: BAMS Under graduate Final year

2: MD Scholar, Department of Manovigyan evum Mansaroga

3: Professor and Head of Department, Department of Manovigyan evum Manasaroga, Sri

Dharmasthala Manjunatheshwara College of Ayurveda and Hospital, Hassan

*Corresponding Author: Niveditha CN

Received $19^{\text {th }}$ April 2021; Revised $20^{\text {th }}$ June 2021; Accepted $29^{\text {th }}$ July 2021; Available online $1^{\text {st }}$ Oct. 2021

https://doi.org/10.31032/IJBPAS/2021/10.10.1012

\begin{abstract}
Background: Academic pressure creates immense stress, anxiety and depression for students of all age groups and is a cause of concern among college students. Test Anxiety is a pertinent issue gaining more importance with the increase in competition especially at the higher level of education [1]. The result of the exams is perceived to be threatening and this fear is transformed into test anxiety and stress that can have serious implications in terms of performance and health of the students [2].
\end{abstract}

Objective: To assess the prevalence of test anxiety in ayurveda undergraduates and also to identify the definite cause for the exam stress and what difficulties students face during the exams due to stress.

Methodology: The study was a descriptive web-based survey study. The participants included 652 undergraduate students of all academic years- first, second, third and final year studying from 8 various Ayurveda colleges of Karnataka, dividing them into south, north, east and west zones including government, private and aided colleges. Study took place from January 15th, 2021, to February 10th, 2021.

Results: Female students experience significantly higher level of test anxiety, Worry, stress as compared to male students. Probable definite cause for exam stress as seen highly in students are fear to recall $(59 \%)$ and last moment study (58\%). According to the students, emotion affect their performance 
negatively, and symptoms like rapid heartbeats, discomfort in stomach, feeling of hopelessness, depression, forgetfulness and self doubt are highly seen in student community.

Conclusion: Female are needed to pay more attention on controlling their level of test anxiety, worry and stress than male students, which could be done through training them. Bearing in mind the causes for test anxiety and difficulties faced by students during exams, different kinds of counseling strategies and relaxation techniques can be used.

\section{Keywords: Test anxiety, under graduate students, causes of stress, psychological problems INTRODUCTION}

Test anxiety has become a common problem among the student community resulting in performance which may affect the academic career of the students. Researchers found that between $25-40 \%$ of students experience test anxiety [1-3]. Student represents the society's investment for future. Their mental health and wellbeing are important not only in its own right but also as a factor contributing to the larger society's well being. Psychological problems among student population varies from $2 \%$ to as high as $50 \%$. At any given time if one randomly examines the student wellbeing one can find that every 10 students, one will have emotional conflicts severe enough to merit professional help [4]. The concept of test anxiety has released different explanations in literature due to the manner and form in which it manifests. Test anxiety involves an interaction among physical, emotional tension, autonomic nervous system arousal, cognitive worry, doubt in one's abilities and behavioural responses that interfere with test preparedness [5]. Test anxiety is a form of social evaluation anxiety experienced by individuals in an environment of assessment. In general, the term Test anxiety is a psychological condition in which pupil experiences extreme stress, anxiety, discomfort and irrational fear during or before the examinations [6]. Test anxiety also refers to an unpleasant feeling or emotional state that has physiological and behavioral concomitants and that is experienced in formal testing or other evaluative situations [7]. Based on gender difference, female students are experiencing higher levels of test anxiety compared to male students. Unrealistic expectation of parents from their children, parental pressure that cause greater worry, fear of failure, test irrelevant thoughts, and stronger bodily symptoms, excessive pressure and fear of teachers, inadequate study, poor motivation and lack of selfesteem, poor nutrition and sleeping disturbances, previous experience of poor performance in tests etc. are the main factors 
leading to test anxiety. The components of test anxiety are worry, test irrelevant thinking, tension, bodily symptoms like sweating, tremor, headache, palpitation, nausea, diarrhea etc. Worry, emotion, Cognitive interference and lack of selfconfidence are also considered as the components of test anxiety [8].

College students frequently have more complex problems today than they did over decade ago common stressors in college include greater academic demands, being on your own in a new environment, changes in family relations, changes in social life, exposure to new people ideas and temptations. Some of the salient problems specific to college students are, time pressure, fear of failure, struggle to establish identity, pressure of academic excellence and tough competence. Emotional problems such as Feel inferior to others, not able to think properly, worrying too much, feel life is not worth living. Feel anxious without any apparent reason [9]. Student reacts to college in a variety of ways. For some students college is stressful because it is an abrupt change from high school. For others separation from home is a source of stress. Although some source of stress is necessary for personal growth to occur, the amount of stress can overwhelm a student and affect the ability to cope. Several studies reported Medical students experience more stress. A major stressor for first year medical students is the amount \& complexity of material to be learned. The purpose of this study was to identify the prevalence and causes of test anxiety in Ayurveda undergraduates as number of studies have been carried out to find the prevalence rate of test anxiety in primary and secondary school children. Similarly few studies have been conducted on students of sociology, Business administration, Medical and Nursing [10, 11].

\section{METHODOLOGY}

Design of the Study- The study was a descriptive survey study with the purpose to obtain information from a group of individuals at one point in time and also allowed for a larger number of students to contribute to the study. The objective of the study was to identify the definite cause for the exam stress and what difficulties students face during the exams due to stress.

Location of the Study- Participants completed a web-based survey. An invitation to participate in this survey was distributed to the principal of 8 Ayurveda colleges of Karnataka, dividing them into south, north, east and west zones including government, private and aided colleges through an email 
message that included a link to the online survey.

Time Period for Study- The study took place from January 15th, 2021, to February 10th, 2021.

Enrollment Information- The study's potential participants included 652 undergraduate students of 8 Ayurveda colleges through stratified sampling method. The participants were estimated to be ages 18 to 22 years old. The minimum age was established at 18 years old because it was necessary for participants to have completed at their Pre University. The upper age criterion was based on the expectation that the oldest participant would fall under age 23 and above as participants were expected to come from a variety of geographic regions.

Subject Type- Participants in this study were undergraduate students of all academic yearsfirst, second, third and final year studying Ayurveda of various college of Karnataka.

Participant Source- The participants for this study were selected from Ayurveda medical colleges in Karnataka.

- Government Ayurveda Colleges of Bangalore and Mysore.

- Two aided Ayurveda Colleges of Hubli and Udupi
- Four private Ayurveda colleges of Hassan, Bangalore, Koppala, and Vijayapura.

Recruitment- Upon Institutional ethics committee approval of the study, the researcher sent an email study invitation to principal/coordinator of 8 colleges as mentioned above one month before examination. The email invitation provided basic study information and study participation criteria, as well as a link to the web-based survey. The announcement was sent once and was followed by a reminder email after 2 days. After reading the email invitation, individuals willing to participate accessed the survey via a secure online link. Participants then completed the survey during a single online session. Names were recorded of those who accessed the link and email addresses were not re-used or disclosed to any outside individuals or groups. There was no material incentive or remuneration for participating in the survey.

\section{Subject Inclusion Criteria}

Participants included in the study were ayurveda undergraduate students of all academic years $\left(1^{\text {st }}, 2^{\text {nd }}, 3^{\text {rd }} \& 4^{\text {th }}\right.$ BAMS $)$ scoring 3 (moderately high) or above in Westside test anxiety scale. Participants must have been able to speak, read, and write in English in order to participate, since the 
survey was in English with no translation available.

\section{Subject Exclusion Criteria}

- Students experiencing anxiety due to physiological or pathological conditions.

- Known physical diseases or psychiatric conditions that may interfere with preparation \& performance of examination

Data collection- The survey took approximately 5-7 minutes to complete. It began with demographic information about the participating students. The participant then answered questions about their college name and in which academic year they are studying. The remainder of the survey focused on specific information regarding the symptoms (emotional, physical, cognitive and behavioral) they face during exam stress. The survey inquired about their concentration level, worries about recall, fear of failure, low confidence level etc. The survey included open-ended questions as well as free comment space after few of the multiplechoice closed-ended questions.

\section{OBSERVATION AND RESULTS}

Participants in this study were undergraduate students of all academic year-first, second, third and final year with the complaints of exam stress problem were screened with west side test anxiety scale and 652 students who fulfilled the inclusion criteria were selected and registered for the study. Among 652 students, 211 students $(32.30 \%)$ were Male and 441students $(67.70 \%)$ were Female. Report was prepared for collecting detailed history related to test anxiety like age (Table 1), year of studying (Table 2), causes of stress; common symptoms faced due to exam stress, emotional symptoms, cognitive and behavioral symptoms (Table 3); Westside anxiety scale (Table 4). The results have shown that among 652 students, 509 (78\%) said there studies have been impacted due to COVID-19 which might had generated a high anxiety level.

Table 1: Age wise distribution

\begin{tabular}{|c|c|c|}
\hline Age (years) & No. of students & Percentage \\
\hline $18-19$ & 120 & $18.4 \%$ \\
\hline $20-21$ & 393 & $60.2 \%$ \\
\hline $22-23$ & 126 & $19.4 \%$ \\
\hline $23 \&$ above & 13 & $2 \%$ \\
\hline
\end{tabular}

Table 2: Year wise Distribution

\begin{tabular}{|c|c|c|}
\hline Year & No. of students & Percentage \\
\hline First year & 192 & $29.4 \%$ \\
\hline Second year & 197 & $30.2 \%$ \\
\hline Third year & 132 & $20 \%$ \\
\hline Final year & 131 & $20.4 \%$ \\
\hline
\end{tabular}


Table 3: Causes of exam stress, symptoms faced due to exam stress, emotional symptoms, cognitive and behavioral symptoms

\begin{tabular}{|c|c|c|c|}
\hline Causes of stress & $\underline{\text { Percentage }}$ & $\frac{\text { Common symptoms faced due to exam }}{\text { stress }}$ & $\underline{\text { Percentage }}$ \\
\hline 1)Fear to recall large amount of information & $59 \%$ & 1) Rapid heartbeats & $51.2 \%$ \\
\hline 2) Last moment study & $58 \%$ & 2) Discomfort or butterflies in stomach & $45 \%$ \\
\hline 3) Self induced pressure & $40.1 \%$ & 3) Sweating & $41.6 \%$ \\
\hline 4) Studying only few chapters & $22.1 \%$ & 4) Dryness of mouth & $34.5 \%$ \\
\hline 5) Pressure from parents and teachers & $22.1 \%$ & 5) Shaking of hands & $28 \%$ \\
\hline 6) Bad experience in the past & $22.2 \%$ & 6) Nausea & $17.8 \%$ \\
\hline 7) Physically/ mentally unfit & $20.7 \%$ & 7) Sweating & $9.8 \%$ \\
\hline Emotional symptoms & Percentage & Cognitive and behavioural symptoms & Percentage \\
\hline 1)Feeling of hopelessness & $48.5 \%$ & 1) Forgetfulness & $57 \%$ \\
\hline 2) Depression & $40.5 \%$ & 2) Self doubt & $50.6 \%$ \\
\hline 3) Distress & $38.4 \%$ & 3) Negative self talk & $37 \%$ \\
\hline 4) Anger & $34 \%$ & 4) Small movements of hands and legs & $36.6 \%$ \\
\hline 5) Feeling of inadequacy & $30.8 \%$ & 5) Outright avoidance of testing situation & $15.6 \%$ \\
\hline 6) Low self-esteem & $29.7 \%$ & 6) Others & $4 \%$ \\
\hline
\end{tabular}

Table 4: Westside Anxiety Scale

\begin{tabular}{|c|c|c|c|c|c|c|c|c|c|c|}
\hline & Neve & & Rar & true & Som & s true & Usu & true & Alw & true \\
\hline $\begin{array}{l}\text { The closer I am to a major } \\
\text { exam, the harder it is for me to } \\
\text { concentrate on the material }\end{array}$ & 80 & $12.3 \%$ & 155 & $23.8 \%$ & 252 & $38.7 \%$ & 99 & $15.1^{\%}$ & 66 & $10.1 \%$ \\
\hline $\begin{array}{l}\text { When I study for my exams, I } \\
\text { worry that I will not remember } \\
\text { the material on the exam }\end{array}$ & 55 & $8.4 \%$ & 169 & $25.9 \%$ & 214 & $32.8 \%$ & 128 & $19.7 \%$ & 86 & $13.3 \%$ \\
\hline $\begin{array}{l}\text { During important exams, I } \\
\text { think that I am doing awful or } \\
\text { that I may fail. }\end{array}$ & 129 & $19.7 \%$ & 203 & $31.3 \%$ & 167 & $25.61 \%$ & 85 & $13 \%$ & 68 & $10.5 \%$ \\
\hline $\begin{array}{l}\text { I lose on important exams, and } \\
\text { I cannot remember material } \\
\text { that I knew before exam. }\end{array}$ & 93 & $14.3 \%$ & 208 & $31.9 \%$ & 201 & $30.8 \%$ & 95 & $14.6 \%$ & 55 & $8.4 \%$ \\
\hline $\begin{array}{l}\text { I finally remember the answer } \\
\text { to exam questions after the } \\
\text { exam is already over. }\end{array}$ & 85 & $13 \%$ & 218 & $33.4 \%$ & 173 & $26.5 \%$ & 100 & $15.4 \%$ & 76 & $11.7 \%$ \\
\hline $\begin{array}{l}\text { I worry so much before a } \\
\text { major exam that I am to worn } \\
\text { out to do my best on the exam. }\end{array}$ & 87 & $13.3 \%$ & 205 & $31.4 \%$ & 201 & $30.9 \%$ & 95 & $14.6 \%$ & 64 & $9.8 \%$ \\
\hline $\begin{array}{l}\text { I feel out of sorts or not really } \\
\text { myself when I take important } \\
\text { exams. }\end{array}$ & 123 & $18.9 \%$ & 218 & $33.4 \%$ & 201 & $30.8 \%$ & 72 & $11 \%$ & 38 & $5.9 \%$ \\
\hline $\begin{array}{l}\text { I find that my mind sometimes } \\
\text { wanders when I am taking } \\
\text { important exams }\end{array}$ & 111 & $17.1 \%$ & 207 & $31.7 \%$ & 173 & $26.5 \%$ & 109 & $16.6 \%$ & 52 & $8.1 \%$ \\
\hline $\begin{array}{l}\text { After an exam, I worry about } \\
\text { whether I did well enough. }\end{array}$ & 63 & $9.6 \%$ & 155 & $23.8 \%$ & 182 & $27.9 \%$ & 151 & $23.2 \%$ & 101 & $15.5 \%$ \\
\hline $\begin{array}{l}\text { I struggle with written } \\
\text { assignments, or avoid doing } \\
\text { them, because I feel that } \\
\text { whatever I do will not be good } \\
\text { enough. I want it to be perfect. }\end{array}$ & 143 & $22 \%$ & 162 & $24.8 \%$ & 166 & $25.5 \%$ & 82 & $12.5 \%$ & 99 & $15.2 \%$ \\
\hline
\end{tabular}




\section{DISCUSSION}

The study titled "Prevalence Study Of Test Anxiety In Ayurveda Undergraduates of Karnataka Through Semi Structured Online Survey" was conducted in the Department of Manovigyana evum Manasaroga. Subjects were screened from 8 Ayurvedic Medical colleges of Karnataka.

The twenty-first century has become the age of competitions and seen in almost all the fields of life. Every student in his academic career wants to achieve the highest position and has to cross many hurdles. When the student feels stressed, the brain will not be in its best state to accumulate information. This can lead to a vicious cycle - the more they stressed, the less work they do, the more they panic about stressing and not working and the greater the feeling of panic becomes, resulting in even less work being done - and so it goes on. Experiencing panic or stress during an exam can make them forget the information what they have learned. This is less likely to happen if they have put in the hours and prepared well, although sometimes over-preparing can also lead to problems. The moments after an exam spent discussing answers with friends can prove equally worrying, especially if their answers do not correspond with anyone else's. Exam stress can be unpleasant, but is important as it helps any student to perform better. If they do not experience stress when these tests of their ability come about, it is unlikely they will care about their subject or will be motivated to do well. Exam stress can be a very potent stressor, especially when the exam is perceived as important to the individual's future career objectives. Based on the examination results further career of the students are decided. Failure on the exam threatens the loss of this objective, the esteem of others, and self confidence. When under stress, students can find that they are able to go the extra mile and pull from the backs of their minds answers to questions they did not realize they had ever learnt. So, exam stress can be helpful - but only if students can turn all their stress into positive energy.

Out of 652 subjects included in the study maximum distribution was found in age group of 20 to 21 years $(60.2 \%)$. Students in this age category were under graduate students. Most of them had lack of revision due to maladjustment with the new environment.

There was more distribution of gender towards females in the study. Among 652 students, $211(32.30 \%)$ were Male and 441 $(67.70 \%)$ were Female. Among students females are found being more prone to exam 
stress. It has been reported that women generally score higher than men on test anxiety. One of the study conducted in south Africa on Gender differences in scores on test anxiety and academic achievement among South African university graduate students showed that men, who were lower on test anxiety, outperformed women who obtained higher test anxiety scores. Similarly, it was shown that there were gender differences in levels of test anxiety, with women scoring higher than men [12]. Other Study conducted in Pakistan suggested that gender differences are significant where female Masters' students showed a significantly higher level of test anxiety than their male counterparts. It has been observed that those students who are more involved in extracurricular activities they lack complete revision of syllabus and incomplete revision triggers the exam stress [13]. Women seem to be more inclined to experience test anxiety and stress when they are determined to prove their worth in academics especially when the society discourages their right to higher education and makes them feel intellectually inferior to men. This is in accordance with Freud's theory of anxiety in which the second type of anxiety is produced as a result of threat to the ego [14]. Existentialists also emphasize the concept of threat to self esteem which might cause test anxiety amongst female students [15].

In undergraduation, students go through lot of stress and fear. As analysis of the data indicates that most of the students has fear to recall (59\%) and last moment study (58\%). Probable reason for this may be students learning ayurveda has different concepts, and syllabus compared to senior secondary college. Other reason would be sanskrit language as for most of the students its complete new language to learn. In addition to this pressure from parents and teachers, studying only few chapters, time limits may lead to test anxiety. According to the students, emotion affect their performance negatively, sometimes it leads to rapid heartbeats, discomfort in stomach, feeling of hopelessness, depression, forgetfulness and self doubt which are highly seen in student community. Besides COVID-19 crisis had a huge impact on education and academics and might have generated public fear and worry. All these factors might affect students performance and wellbeing and might increase stress levels especially during exams.

SOURCE OF FUNDING ACKNOWLEDGEMENTS-

Authors are thankful to Rajiv Gandhi University of Health Sciences, Karnataka for 
funding this study. And also, appreciation and support to all 8 Ayurveda colleges Principal, staff and students who voluntary participated in the survey study and shared their experiences.

\section{REFERENCES}

[1] Bonaccio S, Reeve CL. The nature and relative importance of students' perceptions of the sources of test anxiety. Learn Individ Differ 2010; 20: $617-25$.

[2] Mwamwenda T S. Gender differences in scores on test anxiety and academic achievement among South African university graduate students. S.-Afr. Tydskr. Sielk. 1994, 24(4).

[3] Cassady J C. Anxiety in schools: The causes, consequences and solutions for academic anxieties. Peter Lang; 2010.

[4] D.L. Farnsworth, Mental health and social change, Ann. Int. Med., 73(1970), 467-472.

[5] Nwokolo $\mathrm{C}$ et al. Effects of Progressive Muscle Relaxation Technique on Test Anxiety among Secondary School Student. Journal of Education, Society and Behavioural Science. 23(3): 1-10, 2017
[6] Arabi F, M Jithesh. Test anxiety and its Ayurvedic approach. International Journal of Herbal Medicine 2017; 5(6): 87-91

[7] Duesek JB. The development of test anxiety in children; Dept of psychology Washington, Seattle, 1980.

[8] Sarason IG. Stress, anxiety and cognitive interferences: Reactions to tests. Journal of Abnormal and Social Psychology, 1984, 46.

[9] Kumarswamy N. Academic Stress, Anxiety and Depression among College Students- A Brief Review. International Review of Social Sciences and Humanities Vol. 5, No. 1 (2013), pp. 135-143

[10] Hamzah F. et al. Assessing Test Anxiety among the First Year Nursing Students' of University Sultan Zainal Abidin. Research J. Pharm. and Tech. 11(4): April 2018.

[11] Desousa A. et al. Test Anxiety amongst Medical and Nursing Students: An Exploratory Study. Journal of Research in Medical Education \& Ethics. Vol. 6, No. 2, July, 2016, pp-59-62 . 
[12] Mwamwenda T S. Gender differences in scores on test anxiety and academic achievement among South African university graduate students. S.-Afr. Tydskr. Sielk. 1994, 24(4).

[13] Eman S. et al. Gender differences in test anxiety and Examination stress. JPPS 2012; 9(2): 80-85.

[14] Freud S. Inhibitions, Symptoms and Anxiety. London: Hogarth Press; 1936. (Original work published 1926).

[15] May R. Contributions of Existential Psychotherapy. In: May R, Angel E, Ellenberger HF (eds.), Existence: A New Dimension in Psychiatry and Psychology. New York: Basic Books, Inc; 1958. p. 37-91. 